\title{
Characteristics of Strategic Partnerships between Differently Successful Companies
}

\author{
Drago Dubrovski ${ }^{1,2}$ \\ ${ }^{1}$ Faculty of Management, University of Primorska, Koper, Slovenia \\ ${ }^{2}$ Department of Management, International School of Social and Business Studies, Celje, Slovenia \\ Email: linnair@siol.net
}

How to cite this paper: Dubrovski, D. (2020). Characteristics of Strategic Partnerships between Differently Successful Companies. Journal of Financial Risk Management, 9, 82-98.

https://doi.org/10.4236/jfrm.2020.92005

Received: April 20, 2020

Accepted: May 30, 2020

Published: June 2, 2020

Copyright () 2020 by author(s) and Scientific Research Publishing Inc. This work is licensed under the Creative Commons Attribution International License (CC BY 4.0).

http://creativecommons.org/licenses/by/4.0/ (c) (i) Open Access

\begin{abstract}
Globalization and rapid technological development, with all their dimensions, influence the change of the strategic orientations of companies in a way that they seek to ensure their continued existence and accelerated development by an in-depth cooperation with other organizations, which, if the four conditions explained are met, can have the characteristics of a strategic partnership. The general objective of a business or equity strategic partnership is to achieve synergy on the basis of integrated, combined and tailored in-depth collaboration, thus an additional joint effect that an individual company would not be able to achieve on its own, while the concrete objectives in each individual alliance and for each participant may be very different. Such an in-depth cooperation also occurs in cases where one of the participating companies is facing severe difficulty, both during the crisis prevention and crisis management periods. However, in these cases, due to the extremely increased risks, some methods of forming alliances are much more common and useful, while others, whose impact on joint crisis management would be too small, are typical only for the alliances between successful companies.
\end{abstract}

\section{Keywords}

Globalization, Partnership, Strategic Alliances, Crisis, Synergy

\section{Introduction}

Globalization is a multidimensional process including economic, political, legal and cultural components and involving countries, organizations and individuals. In business terms, globalization is a state of international trade, investment, financial and human flows, in which more and more regions, countries and companies are becoming involved with their activities, as well as products, services, 
technology, knowledge, information and capital, which in this manner form the global market, though still with special local characteristics. With the globalization of international business or global internationalization, which is erasing or blurring the borders between countries or regions and thus the classic definition of the geographical origin of a product (service), the dimensions of the competitive process are changing as well. Today, globalization is an inevitable starting point which organizations have to take into account in their operation, regardless of the degree of their internationalization, the way they are present on the market and the economic or even non-economic area in which they operate. Competition is intensifying in all (global) markets and merely local (national, regional) competitiveness in the case of open trade (import) prospects for survival and development is no longer sufficient. Globalization requires global competitiveness, which many companies have failed to adapt to in time and are achieving below-average business results, while some have even ended up in an acute crisis or bankruptcy.

A crisis is a short-term unfavourable, undesirable and critical situation in a company, occurring due to both external and internal causes, which directly threatens the continued existence and development of the company (Dubrovski, 2016b; Crandal, Parnell, \& Spillan, 2014; James \& Wooten, 2010; Kovoor-Misra, 2020; Lymbersky, 2014). If changes in the global or local environment are increasingly frequent, faster and less predictable, what rules or prescriptions should the management follow to prevent the company from experiencing a latent or acute crisis and continue to secure (competitive) its existence and (accelerated) development? Due to the specificity of each individual case (company), there is in fact no common, generally valid recipe. Therefore, in the light of current events, business practice is constantly developing new approaches to the problem of how to survive and succeed in such a turbulent, complex and chaotic global environment, all of which are more or less based on the necessity and continuity of the so-called three-step action:

- monitoring events and changes in the company environment,

- transferring present and future characteristics of the environment into company strategies, processes and structures,

- implementing changes in the operation of the company based on the observed and incorporated changes in the environment.

If there can be no universal model for crisis prevention due to the diversity of companies, a company can prepare for the complex and turbulent nature of the environment, which can today be business-friendly from the point of view of conditions, but completely hostile tomorrow, only with the three-step action, which should not be a temporary or intermittent task, but rather a mode of continuous management behaviour. Absolute prevention of a crisis is not possible also due to the external, uncontrollable factors but in this way, a crisis can actually be managed more quickly and its negative effects alleviated. Research has shown that managers who are successful in conditions of higher environmental turbulence understand better how to design an organization (leadership, culture, 
structures, entrepreneurial behaviour) that will be successful in such an environment. Internally-oriented managers operating within the so-called closed system of thought are, on average, less successful (Underwood, 2002: p. 53). The managers who run a company in a highly demanding and open competitive environment develop new or updated business models faster and more successfully than, for instance, the managers in monopolistic or state-owned companies that do not face competition or global competition.

Globalization, with all its dimensions, therefore also influences the development of management theory and practice, as it significantly changes the necessary current and, above all, future competencies. Intense, large-scale, radical and dynamic changes in the environment require organizations or management to employ tailored, creative and innovative managerial development solutions that need to ensure the continued existence and development of companies, all of which are more or less related to international business relationships.

Changes in the contemporary global business environment in all areas are extremely dynamic, turbulent and unpredictable, requiring permanent adaptation of a company through the preparation and implementation of both active and reactive, evolutionary as well as revolutionary ways of business renewal; "hyper-competition", i.e. dynamic and unpredictable environment, requires flexible, innovative and creative organizations that can quickly adapt to the changing rules of the competitive arena.

Technological development, on the one hand, as a cause enables and accelerates globalization, while on the other hand, it is also its consequence. Technological development refers to both the development of technology itself as a set of scientific methods and practical knowledge that with the combination of three production creators enable the manufacture of products from raw materials in an organized, economically rational and socially justifiable manner, and to the development of technology management that involves processes from the development of technology, its introduction and use in the economy or administration, the management of innovation processes through research and development, the introduction of new technologies and prototypes, production processes and other activities in an organization (Bavec, 2001: p. 50).

Technological development brings new and new technologies (Schaeffer \& Sovie, 2019: p. 13; Tardieu et al., 2020: pp. 29-38), which shorten product life cycles of a product, intensify international competitiveness, as they demand better, more innovative, cheaper and faster products from companies. Such development is becoming not only very expensive and consequently risky, but also so demanding that it frequently can no longer be provided with the means from only one source (company). Modern society has evolved from an industrialized one into a digitized one, which is far more risky. Globalization causes faster and simpler movement of products, services, technology, people and information; therefore, in such complex network connections, the degree of interdependence and at the same time also the level of risk are increasing, and people and institutions are becoming more vulnerable in the event of major unpleasant or dan- 
gerous situations. The modern characteristics of technological development introduce the realization that the technological complexity of the production process is also related to the size of (independent or connected) companies, in which it is possible to form sufficiently large development technological and personnel cores, which are increasingly internationally composed.

Globalization and rapid technological development, with all their dimensions, influence the change of the coexistence of companies, when, based on the old principles of independent operation and dealing merely with their own self-sufficiency, the latter will not be able to secure the necessary global competitiveness and thus further existence and development. Namely, companies need to adapt to the rapidly changing environment and find new ways in the form of ensuring the efficiency and success of business operations by improving and adapting the existing business models or developing entirely new models (Huet \& Lahaire-Marcouyoux, 2019; Wildemann, 2017; Wirtz, 2019), which will frequently have to involve participating organizations on the principle of strategic partnership.

\section{Substantive Characteristics of a Strategic Partnership}

Every cooperation between two or more companies is not yet a partnership, even though the relationship between them may be so extensive that they represent each other's greatest, crucial, decisive, i.e. strategic participant in this relationship. A partnership or partnering is a tailored business relationship between two or more participants, based on mutual trust, openness, shared risk and shared benefits, which increases the common competitive ability and business performance, compared to that which the participating organization could otherwise achieve on their own. A partnership is characterized by an in-depth cooperative action with a reciprocal adjustment of the partners' assets and behaviour. In this case, it is not only a matter of parallel interests (alliance) in a particular chosen field, but also of mutual adjustment and coordination between the connected companies, where each participant of the partnership has to give up something to gain something. The contact area between such affiliated companies is significantly larger and therefore more solid than in the case of alliances formed only by summing the potentials of the two companies.

The forms of partnerships can be extremely diverse, but they must all encompass those substantive characteristics of a strategic partnership that importantly distinguish such a relationship between organizations from the classic rivalry or purchase relationship:

- reciprocal adjustment of participants' resources and behaviour: instead of mere summation, characteristic for an alliance,

- inclusion of the development component: partner companies are involved in the joint, combined or complementary development of all programs, projects and activities, or only in some agreed strategically important areas, while development cooperation enhances the interdependence and intensity of cooperation of participants in such a relationship, 
- long-term cooperation: since it is a reciprocally demanding and generally a long-term adjustment of systems, processes, structures and strategies of the participants, which also include a component of joint development, a partnership can only be long-term due to inputs from both sides,

- risk and outcome sharing: in a partnership, on the one hand, all participants share the risks of partnership cooperation associated with different investments and adjustments, but, on the other hand, also share the positive or negative outcomes of the partnership, of course, in the part to which the partnership cooperation relates.

The purpose of today's strategic alliances is to increase the capacities for the continued existence and development or increasing the common (global) competitiveness, which can range from the resolution of a crisis in a partner company to accelerated development and market or technological leadership. Joining a strategic partnership is frequently a response to previously formed vertical or horizontal partnership cooperation of competing companies, with the aim of preventing the competitive lag of companies that were not members of the alliances until then. A company that is developing relatively well on its own will nevertheless, at some stage, begin to lag behind competitors who have joined forces to achieve synergistic effects that an independent company cannot achieve.

\section{Forms of Strategic Partnerships}

The forms of strategic partnerships can range from loose agreements and contracts to strong, forced and formalized alliances that are achieved through ownership change. Strategic partnerships can therefore be categorized into two large groups:

- business (non-equity, non-ownership) association or alliance,

- equity (ownership) alliance.

Strategic alliances, which account for between $60 \%$ and $85 \%$ of all partnerships (Gudergan et al., 2012), are not based on equity, ownership (from "owners") or property (from "property") transactions, as participating companies maintain their legal (status) independence. On the other hand, equity alliances are about a changed ownership relationships, so in this case business cooperation should generally be more intensive and the relationship more long-term, however, equity alliances do not necessarily possess substantive elements of strategic alliances.

Equity alliances are a form of strategic partnership in which equity, ownership, status and statutory changes occur in participating companies. The owners invested the capital as a source of financing the company assets in order to realize common interests in the defined area. The composition of capital shares is also an ownership structure and the extent of the management rights of an individual owner usually depends on the size of these shares. If individual owners sell (transfer, dispose of) their capital shares, the ownership and capital structure generally changes. With equity mergers and joint ventures, the affiliated companies are transformed by changing the legal (and business) status of the partici- 
pating companies, and the basic rules need to be re-established, i.e. the statute of the newly created legal form of the participating companies. Equity alliances thus result in the material (transfer) status re-shaping of the participating companies, which are typically associated with the transfer of all or part of their assets to another company. The types of equity alliances are mergers (acquisitions and amalgamations), takeovers and joint ventures.

The two groups of strategic partnerships may overlap, as equity alliances are frequently intended to achieve the objectives that would be achieved with a business alliance, but in that case coercion through ownership is required if the business alliance cannot be formed otherwise or the latter would not make sense. It is also true that any ownership alliance is not necessarily strategic nor business nor partnership. Therefore, in a concrete case, it is essential to first determine whether the characteristics of a strategic partnership (reciprocity, development component, long-term aspect, sharing of risks and outcomes) are present in this relationship, only then can we judge about the forms of such partnerships.

While an equity merger or takeover is similar to a marriage, a strategic alliance is more like a love affair (The Economist, 1999) or a close friendship. A strategic business alliance is therefore often referred to as a "soft" partnership, while an equity alliance is often understood as a "hard" partnership. In some cases, it would be difficult to define equity alliances as strategic partnerships at first glance, since in such a relationship the stronger company dominates at the expense of the weaker one (instead of the $2+2=5$ effect, we observe e.g. $3+1=$ 5 effect). However, since equity alliances frequently represent the conclusion or the last stage of a previous strategic non-equity cooperation, in this case we can also classify them as strategic partnerships. Such a discussion therefore implies that in certain cases, equity alliances may have the role of strategic partnerships (when it comes to achieving $2+2=5$ outcome), while in other cases their content does not have the character of a partnership (e.g. in the case of direct investments exclusively with financial goals). Takeovers or mergers may, on the one hand, thus represent the conclusion of a strategic alliance and, on the other hand, the highest development stage of a strategic alliance. As already pointed out, in this case, there is no reason not to include equity alliances among strategic partnerships, regardless of whether they emerge as a developmental stage in the evolution of a particular strategic business alliance or arise directly without an evolutionary path. Joint ventures, takeovers and mergers are therefore essentially only a capital-backed form of one or more forms of strategic partnerships, if of course they have such business content.

The result of forming different alliances is the international concentration of industries and services, which means that in terms of number, there are fewer and fewer players (competitors) in individual industries, but with their alliances they are that much larger, while various smaller providers cooperate with this (or in this) alliance one way or another (subcontractors, franchisees, production subcontractors, etc.). 


\section{Possible Objectives of Strategic Partnerships}

The causes (reasons) for the emergence of many strategic partnerships in the forms of strategic business alliances and equity alliances lie in the intensified international competition, technological and general progress and the effects of globalization. The purpose of strategic partnerships is thus maintaining and increasing the common (global) competitiveness, which enables the connected companies to continue their existence and accelerate their development in the harsh business environment. The general objective (basic motive), on the basis of an integrated, combined and tailored in-depth cooperation, is to achieve synergy, thus an additional effect that an individual company would not be able to achieve on its own. The specific objectives (motives), however, may be quite different in each individual alliance and for each participant.

The objectives of forming alliances can be strategic when it comes to strategic partnerships, operational, when it comes to pursuing tactical and implementation common tasks, and internal, when it comes to managing purely internal relationships. The specific objectives of an in-depth and more demanding strategic cooperation usually relate, on the one hand, to solving development problems and, on the other hand, to seizing opportunities, which means that it is either about eliminating the deficit in available resources or the optimal and complementary synergistic exploitation of available resources and capabilities of the participants in an alliance, who, as individual companies, do not master all the key areas of activity or this is not worth it for various reasons.

A strategic partnership is generally always based on finding a synergistic effect by combining the resources and capabilities of the companies involved. Synergy (Gr. syn-s, z; ergon-work) means joint action, cooperation of several factors, forces, organs, individuals, etc. and can be conceptualized as a general, universal principle of the interconnection of the operation of various factors and forces in nature and society (Sruk, 1980: p. 312). By working together, as a whole (=system), we can achieve more than each by himself, the synchronization (=harmonization into a whole) of our energies generates more than the sum, i.e. synergy (Mulej, 2000: p. 25). Synergy as a collaborative and integrative effect can be written in the form of different equations, e.g. $2+2=5,1+1=3,2+2>4,1$ $+1=22$, etc., as a joint action of the parts leading to a better outcome than that which could be achieved in its individual operation.

The synergistic exploitation of available resources refers to the combination of different physical (material), financial and intellectual resources of the participants in an alliance in such a way that their value is greater than the sum of their individual values (Devine, 2002: p. 9). In strategic alliances, the synergy is the difference between the value of connected (merged, participating) companies and the total value of separate companies before the alliance:

$$
\text { Synergy }=V a b-(V a+V b)
$$

$V a b$ - the value of a connected (merged) company. 
$V a, V b$ - the value of the companies before the alliance (merger).

The value of connected companies, of course, does not increase by itself by entering a strategic alliance, but stems from cost savings, increased revenues, process improvements, accelerated development, financial engineering, tax benefits, etc. as a result of the reciprocal adjustments made by the participants of the alliance. In a simplified and summarized manner, the source of synergistic effects can be found:

- on the side of revenues, which are increasing or improving in their composition (impact on profitability),

- on the side of costs, which are decreasing or improving in their composition (costs in the function of revenues).

In the case of equity mergers and takeovers, the value synergistic equation may be the following (Gaughan, 1999: p. 120):

$$
\mathrm{NAV}=V a b-[V a+V b]-P-E
$$

$\mathrm{NAV}-$ net acquisition value.

$V a b$ - the value of a merged company.

$P$-premium paid for $b$.

$E$-costs of the acquisition process.

$V b-$ market value of stocks $b$.

$V a$-assessment of own value $a$.

The competitive advantages of companies connected in a partnership or merged companies may often be hidden, so identifying and measuring them can be difficult. The combinations of motives for mergers are different and multifaceted, and the publicly presented motives need not be the real ones that actually influence the decision to form an alliance. However, in the long run, partnerships can only be driven by economic motives, as the negative effects of a failed alliance can quickly reveal the hidden motives. The possible objectives and sub-objectives of individual strategic partnerships are outlined below (Table 1).

Given the focus of the research in this paper, we continue to be interested in the reasons why a strong, healthy, well-functioning company would want to connect-according to the criteria of a strategic or equity partnership-with a company in difficulty or even an acute crisis, when there is an extremely high risk of chain transfer of problems to the successful company.

\section{Reasons for Strategic Alliances between Differently Successful Companies}

For many companies or industries, engaging in strategic partnerships at some stage of development is not only a strategic possibility and opportunity, but a business necessity, as only in this manner they will be able to maintain a competitive market position in the future and prevent an acute crisis. Forming a partnership rewards companies, which can change traditional perceptions of the boundaries of organizations-and punishes companies that are not capable of these changes (Rackham, Friedman, \& Ruff, 1996: p. 7). On the other hand, stra- 
tegic partnerships and equity alliances can also help to eliminate the crisis in a company, in which the available resources of partner companies are also included in the process of crisis treatment and the synergistic effects are sought also for those participants who are not in trouble in such an alliance.

Table 1. Six groups of potential objectives of forming strategic business and equity alliances.

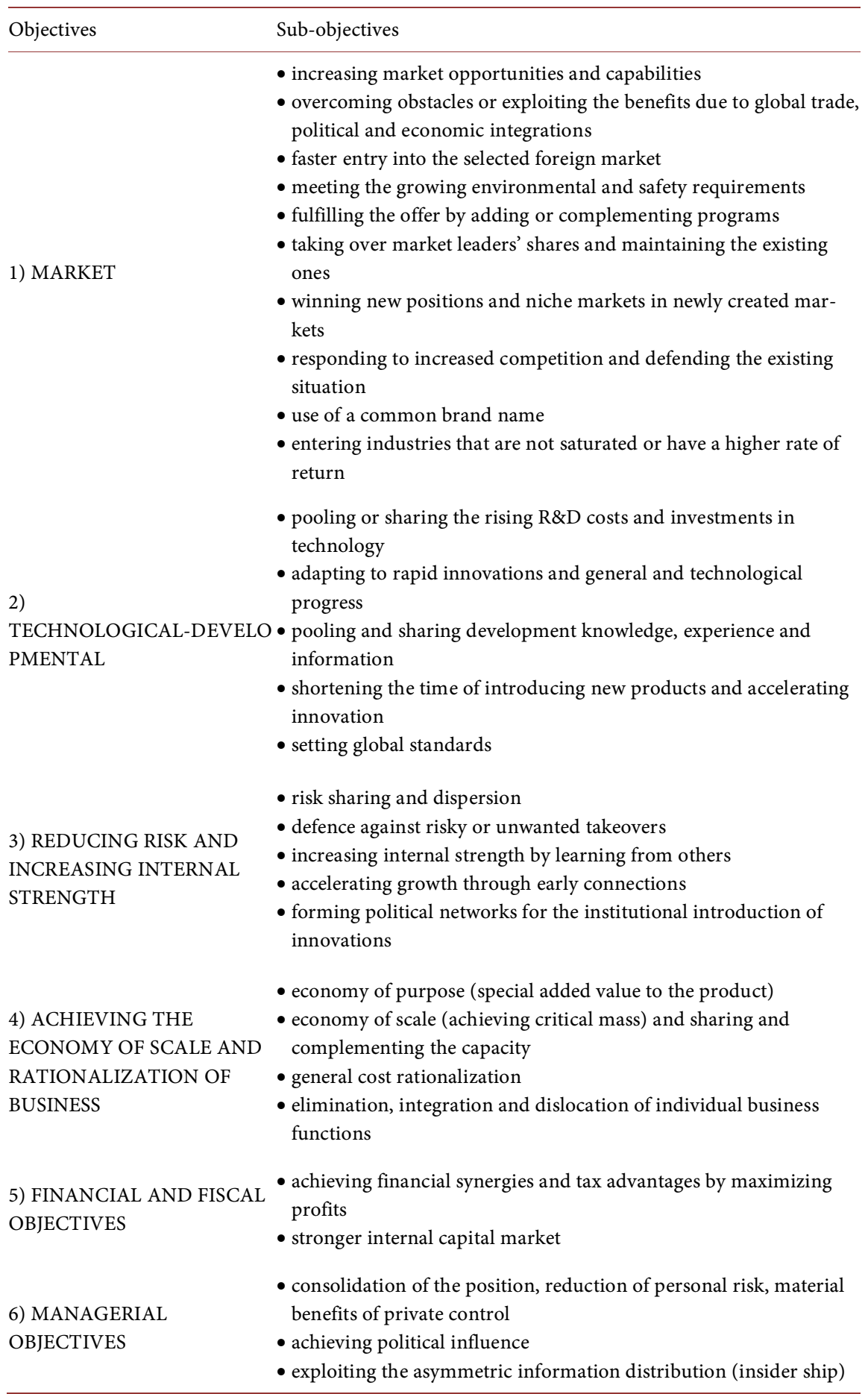

(Author's research). 
When it comes to strategic business or equity alliances in cases where one of the participating companies is in crisis ("ugly duck"), such an alliance can make it easier for such a company to overcome the problems encountered. Since in this case it is about connecting an economically stronger and more successful company with a weak one, the latter cannot count on an equal position in the integration processes, which is actually a sacrifice for it, as is the case in all crisis management cases. Strategic business partnerships and equity transformations are important both in crisis prevention and crisis management periods. According to some research (Faulhaber \& Landwehr, 1996: p. 267), in 40\% - 50\% of cases, the component of the concept of business turnaround is equity merger and takeover. In such cases, the objective of a company in difficulty is also frequently recapitalization, which reduces the debt burden in the cash flow so that it is in line with borrowing options, or it is about asset restructuring, with which the constitutional structure (the ratio between fixed and current assets), the liquidity structure (the ability and time required to convert non-monetary assets into cash) or the financial (equity) structure (structure of sources of funds) should be improved.

The reasons for a successful and powerful company to enter into a form of a partnership with a company in acute crisis ("ugly duck"), where there is a serious threat of a negative effect of a chain reaction of the crisis, stem from the material or immaterial assets held by the company in crisis, for example:

- commercially verified production and sales or service program, which the company cannot properly develop and market due to the lack of all other necessary potentials (financial, personnel, technological, etc.);

- advanced technology, which cannot be optimally exploited because the company has problems in sales, marketing and finance areas,

- an excellent team of professionals who are unable to demonstrate and use their knowledge and skills because the company has insurmountable financial or other problems,

- intellectual property rights (patents, trademarks, standards), which are dormant because the company cannot use them productively due to its own problems,

- the status of a company with special rights (e.g. a social enterprise) that could be more effectively exploited in the partner network of companies,

- such fixed (e.g. land) and current assets (e.g. investments) with which a partner can achieve significantly greater efficiency and return,

- diversified distribution network at home or abroad, which it cannot maintain due to financial problems, but which allows a partner to enter the market immediately.

For a successful company to avoid the dangers stemming from an alliance with a company in crisis, in practical cases, pre-alliance measures have to be taken first, which refer to the introduction of highly radical remedial measures in the company in crisis if necessary (voluntary or compulsory settlements, disinvestments, balance sheet "cleaning", even programmed-controlled bankrupt- 
cies, etc.), or less risky measures (such as takeover by buying the assets of a company in crisis, buying from bankruptcy).

\section{The Prevailing Ways of Forming Equity Alliances to Overcome a Crisis}

Partnerships between differently successful companies have to be formed with extreme care and planning in order to eliminate the risks posed by in-depth cooperation with a company in serious difficulty as much as possible, so the number of ways or techniques is much narrower than in connecting successful companies. In addition to the findings from the previous theoretical discussion and previous research (Dubrovski, 2016a; Dubrovski, 2009), in which it was determined, among other things, that $1 / 4$ of Slovenian manufacturing companies from the list of the largest companies according to annual revenues were able to overcome or manage an impending or already existing crisis with the help of strategic partnerships and equity alliances from the period 2010-2015, the findings were added in this paper regarding the methods (techniques) of forming equity alliances with takeovers, which are considered typical examples of alliances between differently successful companies.

The empirical part of this paper was based on the data from 45 cases of Slovenian companies from the period 2014-2018, which were either 1) in a state of acute crisis, as evidenced by publications in business media (e.g. http://www.finance.si/), by publications of insolvency proceedings (https://www.ajpes.si/eobjave/) or their annual reports (https://www.ajpes.si/fipo/), which describe the methods of compulsory settlement, major business or financial restructurings, reduction of business volume and layoffs, emergence of insolvency, etc.), or 2) the studied companies were successful, but they nevertheless entered into equity alliances with takeovers of unsuccessful companies or even of those in an acute crisis.

In takeovers, one company (acquiring company) acquires in another company (acquired, target company, target) the so-called controlling share of ownership or management rights, with both companies continuing to exist unchanged legally and in status. On the basis of the carried out takeover, however, the business policy of the acquired company is likely to change and restructuring in several areas, etc. is expected, with the aim of increasing the now joint competitiveness, so that significant business changes or adjustments occur.

The discovered methods of forming equity alliances with takeovers in the case of the studied Slovenian companies are listed in the following table with the frequency label: 1-rare (least common), 5-most common (Table 2) The key reason why some methods are used more often while others are very rare is because of the significantly higher risk posed by an intense alliance between a healthy company and a company in difficulty, and, above all, the acquiring company wants to avoid cash payments, especially those intended for previous owners (who are directly or indirectly responsible for the occurrence of problems in the target company). 
Table 2. The frequency of methods of forming equity alliances with takeovers.

\begin{tabular}{|c|c|c|}
\hline No. & Takeover method & $\begin{array}{l}\text { Participating company in crisis } \\
\text { (5-common, 1-rare) }\end{array}$ \\
\hline 1 & $\begin{array}{l}\text { conversion of the debt claims on the target company in diffi- } \\
\text { culty into that company's share capital }\end{array}$ & 5 \\
\hline 2 & purchase of fixed assets of the company in difficulty & 5 \\
\hline 3 & $\begin{array}{l}\text { increase of share capital with recapitalization (payment to the } \\
\text { company in difficulty) }\end{array}$ & 4 \\
\hline 4 & $\begin{array}{l}\text { purchase of the target company in difficulty by means of a } \\
\text { leveraged buy-out (LBO) }\end{array}$ & 3 \\
\hline 5 & $\begin{array}{l}\text { agreed takeover of control with minority equity participation } \\
\text { but greater voting power }\end{array}$ & 3 \\
\hline 6 & combination of stock and asset purchases & 3 \\
\hline 7 & cash payment to existing owners (cash purchase) & 2 \\
\hline 8 & $\begin{array}{l}\text { gaining control by reducing capital and withdrawing own } \\
\text { stocks }\end{array}$ & 1 \\
\hline 9 & $\begin{array}{l}\text { mutual exchange of stocks when a larger company acquires a } \\
\text { smaller controlling stake at the same value of the stocks } \\
\text { exchanged }\end{array}$ & 1 \\
\hline
\end{tabular}

(author's research).

With a debt-to-equity swap (which is a non-monetary recapitalization for a company), which is most commonly used in compulsory settlement procedures, the creditors lose their creditor status and become owners, thereby taking on the business risk-from a less risky investment they enter a riskier one, with which they acquire management rights in the amount of converted debt (debt-to-equity swap). Such a swap is not usually performed at par-one unit of debt for one unit of equity, as the exchange rate must also include the uncertainty and risk factor. A debt-to-equity swap can, under certain conditions, be a much better decision for a creditor than a debt write-off, while it can represent an extremely attractive way for a company in difficulty to reduce its liabilities and improve its capital structure.

In the case of asset deals, the acquirer does not purchase capital (stocks, share) from the current owners by liabilities (share deal), but the fixed assets used by the target company in the business process (by assets) and the purchase contract is not concluded by the stockholder, but by the company itself (or its management); the purchase price of the assets sold is received by the company and not by its stockholders. In this way, the company that sold the assets has virtually transferred the business to the acquirer, who will be able to continue with the activities (often with the same workers), while the target company will receive the purchase price for the sold assets, which it will be able to use for debt repayment, business conversion, payment to its stockholders or termination of activities (liquidation). The advantage of such a transaction is the ability to choose the assets and liabilities acquired, and the risks of unknown and undisclosed liabilities are substantially reduced or non-existent at all. The downside of such a transaction 
is that various bonuses, consents, certificates, standards, concessions, special statuses, trademarks and other industrial property rights, involvement in sales and purchasing channels, etc., which cannot be transferred without the consent of third parties, are not automatically transferred to the buyer of the assets. Such transactions can be less favourable from a tax perspective (possibility of double taxation) and can frequently be more complex (mostly related to obtaining the consent of the majority of stockholders).

A takeover of the target company in difficulty may also occur in the following manner: instead of payment to the existing owners, this money is received by (their) company, increasing its capital by an additional amount paid (recapitalization of the company). In this case, the purchase price is thus not received by the stockholders of the target company, but by the company itself, and the existing stockholders remain the owners of that company, of course in a proportionately reduced extent. As the company in this manner became larger in terms of equity in the amount of the new owner's investment, the ownership relationships subsequently changed. The reason for the existing owners to allow a new investor to become an acquiring stockholder is that such a strengthened company will now be able to achieve different target synergies, thus continuing to secure its existence and development (and stock value); otherwise, the company might be in danger of collapsing, or it could be about some more complex, related business.

In the case of a leveraged buy-out (LBO), the buyer purchases the stocks of the target company with funds obtained solely or mainly through loans, in which the stocks that are subject to purchase and possibly the assets of the target company are used to secure the loan. These are thus transactions in which the stocks of the company or its assets are purchased with borrowed funds, which results in a new equity structure that is primarily a debt (loan commitment). Loans and interest are paid from the future returns of the acquired company. The largest part of the premium an investor is prepared to pay, in addition to the possibility of improving the efficiency of the acquired company in difficulty, should stem from tax savings (DePamphilis, 2008: p. 555).

The agreed takeover of control with minority equity participation, which gives the acquiring company greater, disproportionate voting power, is often the result of the acquirer's efforts to reduce risks on the one hand, and, on the other hand, of transferring management and leadership rights to the acquirer on the part of the owners of the company in difficulty, who still remain hopeful that their investment in the company in difficulty will retain some value.

One of the possible combined techniques is a two-step process of buying the assets in the form of taking over the stocks of the new company. A company that wishes to sell certain assets establishes a subsidiary to which it transfers all those assets that are to be the subject of the sale, and then sells to the buyer the stocks of that subsidiary. In this way, the buyer and seller can avoid paying taxes on the sale of individual assets, should such an obligation exist. 
In the case of payment in cash to the owners, the buyer (investor, acquirer) acquires the stocks of the target company from its previous owners in exchange for money or any other equivalent. The purchase contract with the buyer is concluded by the stockholders and not by the company or its management. The advantage of such a transaction is that the identity of the target company remains unchanged since the company retains its name and all contractual and other relationships with the environment. An important advantage in addition to transparency is the relatively simple and fast implementation of such a transaction, which does not require the consent of the management of the target company. An important disadvantage, however, is taking over the unknown and undisclosed liabilities of the target company, since the buyer takes over the company with all its assets and known and unknown liabilities.

When a company reduces its capital by withdrawing its own stocks, the shares of the existing owners are proportionally increased for those withdrawn, "deleted" stocks, thereby enabling them to gain control and, consequently, the status of the acquirer. If a company has $50 \%$ of its own stocks and the largest stockholder has a $40 \%$ share, its share will increase to $80 \%$ by withdrawing its own stocks, giving this stockholder full control of the company without any risk of the share in its own stocks being acquired by someone else. However, by acquiring the majority ownership, the acquirer can begin to invest significantly more in the acquired company.

An equity merger can also occur without the involvement of cash assets, when a larger company takes over a smaller company in terms of value by either stockholders or participating companies (if they have their own stocks) exchanging stocks in the same total value (stock-for-stock). In this way, the larger company will become the majority stockholder in the smaller company and the latter will acquire a few percent of the stocks in the acquiring company with the exchange, or the acquirer will transfer to the stockholders of the taken over (acquired) company an appropriate share of the stocks of its company in exchange. In an amalgamation, the stockholders of the previous companies that cease to exist receive the stocks of the new company in exchange. In the case of a company in crisis, this method is very rare as it does not contribute to the elimination of the current situation.

For a successful takeover of a target company in difficulty three key rules have to be followed (DePamphilis, 2008: p. 528): knowing what is being purchased, not overpaying the purchase and being able to improve the efficiency and success of the target company, which then, of course, affects the frequency of individual takeover methods. In such cases, the so-called "bust-up" takeovers are also known when a part of the acquired target company is sold or disinvested upon takeover. Divestiture is often the first source of funding of equity takeovers, when the acquirer then sells some parts of the acquired company that are not strategically important for further development and reimburses itself for the funds required for the takeover. Management (and owners) sometimes want to 
gain control of the other, target company by any means necessary, so they opt for challenging and dangerous equity adventures, especially when the target company is in difficulty, even though alternative ways of achieving strategic objectives may be less risky and less expensive.

In the mentioned cases, the management of the target company in crisis generally considers the intended takeover by a healthy company as a friendly one, as it believes that the target company will be able to secure its continued existence and development with the help of the acquiring company. This is precisely why in business practice we often come across a misunderstanding of the management as to what a strategic partnership is supposed to be, when the management of a company in crisis is rather illusively relying on the current situation to be eliminated as soon as they find a "strategic partner", they just have to wait until then. In a one-way collaboration, they envision a strategic partner as someone who will bring them fresh funds to cover all their old matured liabilities and to develop new projects, someone who will provide them the latest technology and access to new markets abroad (deus ex machina), but at the same time will not interfere with the existing management and the established (unsuccessful) operation of the company. This is why the management will not be satisfied with every "strategic partner". The cruel truth is different, however, since a potential acquirer of a company in difficulty will turn the latter "upside down" with radical measures and in all likelihood "thank" the existing management for the work done so far, since such a transaction must result in a synergistic effect from a two-way action. The statement in a business plan that a company in crisis is in search of a strategic partner in fact means that it is not actually taking any necessary measures to remedy the crisis.

\section{Conclusion}

Globalization and rapid technological development, with all their dimensions, influence the changing of the coexistence of companies, when, according to the old principles of independent activity and dealing merely with their own self-sufficiency, they will not be able to secure the necessary global competitiveness and thus further existence and development. Namely, it is necessary to adapt to the rapidly changing environment and find new ways in the form of ensuring the efficiency and success of business operations by improving and adapting the existing business models or developing entirely new models, which will frequently have to involve the participating organizations on the principle of strategic partnership.

A strategic partnership is a tailored business relationship between two or more participants based on mutual trust, openness, shared risk and shared advantages, which enhances competitiveness and common business performance compared to the one the organizations involved would be able to achieve on their own. The forms of partnerships can be extremely diverse, but they must all encompass those substantive characteristics of a strategic partnership that significantly dif- 
ferentiate such a relationship between organizations from a classic rivalry or purchase relationship: a reciprocal adjustment of participants' assets and behaviour, involvement of the development component, long-term cooperation and sharing of risks and outcomes. The basic objective of a business or equity strategic partnership is to achieve synergy through integrated, combined and tailored in-depth cooperation, that is, to achieve an additional joint effect that an individual company would not be able to achieve on its own, while concrete objectives may be quite different in each individual relationship and for each participant.

Strategic business partnerships and equity transformations are important both in crisis prevention and crisis management periods. The reasons for a successful and powerful company to enter into a partnership with a company in an acute crisis, where there is a serious threat of a negative chain reaction of a crisis, may stem from the material or immaterial assets of the company in crisis, for instance the commercially verified production and sales or service program, advanced technology, an excellent team of experts, intellectual property rights, special rights status, fixed and current assets, an extensive distribution network at home or abroad, etc.

Partnership alliances between differently successful companies have to be formed with extreme care and planning in order to eliminate the risks posed by an in-depth cooperation with a company in serious difficulty, so the number of ways or techniques is much narrower than in forming alliances between successful companies. By analyzing 45 cases of Slovenian companies from the period 2014-2018, which were either in a state of an acute crisis or were successful companies, but nevertheless entered into equity alliances by taking over unsuccessful companies or even those in an acute crisis, it was determined that the most commonly used methods were 1) conversion of debt claims on the target company in difficulty into the share capital of that company (debt-to-equity swap) and 2) purchase of fixed assets of the company in difficulty, since precisely with these methods the risk of the acquiring company is reduced on the one hand and on the other hand, the greatest benefit for a company in crisis is achieved. Another finding of the case analysis revealed that the management of a target company in crisis frequently misunderstands the characteristics of a two-way strategic partnership, namely they believe that the current crisis will be eliminated when the acquiring company will unilaterally provide its assets and capabilities.

\section{Conflicts of Interest}

The author declares no conflicts of interest regarding the publication of this paper.

\section{References}

Bavec, C. (2001). Management tehnologije. In Management v evropskem okolju. Zbornik 1. Strokovnega posveta (pp. 19-34). Koper: Visoka šola za management. 
Crandall, W. R., Parnell, J. A., \& Spillan J. E. (2014). Crisis Management. Los Angeles, CA: Sage.

DePamphilis, D. M. (2008). Mergers, Acquisitions, and Other Restructuring Activities. Burlington, VT: Elsevier.

Devine, M. (2002). Successful Mergers. London: The Economist.

Dubrovski, D. (2009). Strateške poslovne zveze in kapitalske povezave. Koper: Faculty of Management.

Dubrovski, D. (2016a). Handling Corporate Crises Based on the Correct Analysis of Its Causes. Journal of Financial Risk Management, 5, 264-280. https://doi.org/10.4236/jfrm.2016.54024

Dubrovski, D. (2016b). Strategic Partnership and Equity Alliances in the Function of Crisis Prevention and Elimination. Modern Economy, 7, 1385-1395.

https://doi.org/10.4236/me.2016.712128

Faulhaber, P., \& Landwehr, N. (1996). Turnaround: Management in der Praxis. Frankfurt: Campus.

Gaughan, P. A. (1999). Mergers, Acquisitions, and Corporate Restructurings. New York: John Wiley \& Sons.

Gudergan, S., Devinney, T., Richter, N. F., \& Ellis, R. S. (2012). Strategic Implications for (Non-Equity) Alliance Performance. Long Range Planning, 45, 451-476. https://doi.org/10.1016/j.lrp.2012.09.002

Huet, J.-M., \& Lahaire-Marcouyoux, Ch. (2019). Organisation des entreprises: Quels changements? Montreuil: Pearson France.

James, E. H., \& Wooten, L. P. (2010). Leading under Pressure. New York: Routledge.

Kovoor-Misra, S. (2020). Crisis Management. Resilience \& Change. Los Angeles, CA: Sage.

Lymbersky, C. (2014). The International Turnaround Management Standard (Version 1.5). Hamburg: Turnaround Management Society.

Mulej, M. (2000). Dialektične in druge mehkosistemske teorije. Maribor: Ekonomsko-poslovna fakulteta.

Rackham, N., Friedman, L., \& Ruff, R. (1996). Getting Partnering Right. New York: McGraw-Hill.

Schaeffer, E., \& Sovie, D. (2019). Reinventing the Product. How to Transform Your Business and Create Value in the Digital Age. London: Kogan Page.

Sruk, V. (1980). Filozofsko izrazje in repertorij. Murska Sobota: Pomurska založba.

Tardieu, H., Daly, D., Esteban-Lauzan, J., Hall, J., \& Miller, G. (2020). Deliberately Digital. Cham: Springer Nature. https://doi.org/10.1007/978-3-030-37955-1

The Economist (1999). Mergers and Alliances. The Economist, 15th May, 81-82.

Underwood, J. (2002). Complexity and Paradox. Oxford: Capstone.

Wildemann, H. (2017). Neue Geschaftsmodelle in der Industrie 4.0. München: TCW Transfer-Centrum.

Wirtz, B. W. (2019). Digital Business Models. Cham: Springer Nature. https://doi.org/10.1007/978-3-030-13005-3 